\title{
The Flow Rate Characteristics of CO Gas Emissions Using Simflow
}

\section{1}

\author{
Eka Febriyani ${ }^{1, a}$ and Nuroh Hidayati ${ }^{1}$
}

\author{
${ }^{1}$ Department of Physics, Faculty of Mathematics and Natural Sciences, University of Jember, \\ Jalan Kalimantan No 37 Kampus Tegalboto Jember \\ aekafebri6861@gmail.com
}

\begin{abstract}
Carbon monoxide (CO) is a type of pollutant produced by industrial activities and is emitted through gas exhaust flues. Simulation activities are considered to provide a lot of information regarding the distribution of $\mathrm{CO}$ gas flow in the air. This paper will analyze the velocity and pressure distribution characteristics of $\mathrm{CO}$ gas to predict the accumulation of $\mathrm{CO}$ gas at various variations in the distribution distance of the gas. Simulation activities are carried out using SIMFLOW 3.1, a software capable of simulating fluid dynamics by emphasizing the ease of application. The simulation results show that the flow rate of $\mathrm{CO}$ gas is proportional to the amount of gas pressure generated at each distribution distance of the gas. The $\mathrm{CO}$ gas flow shows a fairly stable movement when identified at a distance of more than $30 \mathrm{~m}$. This indicates that a mass of $\mathrm{CO}$ gas will be transmitted in the same amount over a distance of up to $70 \mathrm{~m}$. The largest gas accumulation was obtained at a distance of $20 \mathrm{~m}$ from the source, which was indicated by the smallest gas flow velocity of $3.87 \times 10^{-3} \mathrm{~m} / \mathrm{s}$.
\end{abstract}

Keywords: Simflow 3.1, Chimney, CO.

\section{Introduction}

Carbon monoxide (CO) is the most abundant pollutant element compared to other pollutants in the atmosphere. Statistical data shows that the amount of $\mathrm{CO}$ gas has a percentage of $80 \%$ $90 \%$ in the earth's surface area [1]. Environmental conditions much influence the distribution of $\mathrm{CO}$ in an area. Microorganisms can eliminate this distribution in the soil. Open land, which is rare nowadays, causes the amount of $\mathrm{CO}$ gas to increase. Carbon monoxide is a primary pollutant source. These pollutants play a role in global climate change, especially global warming. Carbon monoxide is a dangerous pollutant, which at high gas levels can cause death in humans. Carbon monoxide (CO), which is sucked into the lungs, will participate in blood circulation and will block the entry of oxygen that the body needs [2]. This can occur because $\mathrm{CO}$ gas is a metabolic poison, so it reacts metabolically with blood. Very high concentrations of $\mathrm{CO}$ gas can cause death [3]. As a result of carbon monoxide for health is not irritating but very dangerous/poisonous, it is called the "silent killer". CO gas is hazardous if inhaled by humans. It will replace the position of oxygen related to hemoglobin in the blood. CO gas reaction with hemoglobin is 200 times more dangerous than the reaction of oxygen with hemoglobin [4]. The flow characteristics of $\mathrm{CO}$ gas as fluid are essential to study to determine the extent of CO gas distribution in an area. We can make preventive efforts to analyze areas that are relatively safe from accumulated pollutant gases. The pattern of the distribution of pollutant gases is vital to explore so that the gas exhaust can release pollutant gas as high as possible. This is necessary so that pollutants do not easily contaminate the chimney area, which is close to the ground. Through a simulation activity, fluid flow characteristics can be developed without relatively high experimental costs. In this research, the fluid flow characteristics simulation will be performed under distance variations using the computational fluid dynamic (CFD) method. This CFD studies the prediction of fluid flow and heat transfer by solving mathematical equations. CFD 
has been widely used in various problems related to fluid flow, one of which is dispersion [5]. Previous researchers have carried out the flow characteristics of the fluid (gas), which were analyzed in a certain gas channel. Using the ANSYS CFD FLUENT software, Fathoni (2018) analyzed circular pipes' fluid characteristics with turbulent flow types [6]. Mahan (2009) investigated the spread of $\mathrm{SO}_{2}$ gas from stack emissions using Computational Fluid Dynamics (CFD) [7]. Based on research from Mahan, we will research the flow rate of CO gas and its characteristics. Fluid is a substance that cannot withstand the forces and shear stress applied to it in an equilibrium state. Fluid is elementary to follow the shape of space because the fluid resistance to deformation is minimal.

In general, fluid can be divided into two, namely static and dynamic [8]. The fluid has several basic properties that can be used to differentiate between one type of fluid state and another. The different parameters include specific gravity, density, pressure, viscosity, and temperature [9]. Research on fluid flow in home industrial chimneys uses the CFD method using SIMFLOW 3.1 software. This research was conducted by varying the size of the pollutant distribution distance of $\mathrm{CO}$ gas in the chimney at a certain point. The results of this study are expected to provide additional lessons about the distribution of pollutants because in Indonesia, the model for simulating the spread of contaminants has not been widely used, while the need for the food or electricity industry is increasing, so there is a need for more studies on this research. In general, the fluid flow equation used in this simulation process is the Navier-Stokes equation, which includes the continuity equation and the momentum equation [10].

a. Continuity Equation

$\frac{\partial \rho}{\partial \mathrm{t}}+\frac{\partial(\rho \mathrm{u})}{\partial \mathrm{x}}+\frac{\partial(\rho \mathrm{v})}{\partial \mathrm{y}}+\frac{\partial(\rho \mathrm{w})}{\partial \mathrm{z}}=0$

b. Momentum Equations Momentum towards the $x$-axis:

$-\frac{\partial \mathrm{p}}{\partial \mathrm{y}}+\frac{1}{\mathrm{R}_{\mathrm{r}}}\left(\frac{\partial \tau_{\mathrm{xx}}}{\partial \mathrm{x}}+\frac{\partial \tau_{\mathrm{xy}}}{\partial \mathrm{y}}+\frac{\partial \tau_{\mathrm{xz}}}{\partial \mathrm{z}}\right)=\frac{\partial(\rho \mathrm{u})}{\partial \mathrm{t}}+\frac{\partial\left(\rho \mathrm{u}^{2}\right)}{\partial \mathrm{x}}+\frac{\partial(\rho \mathrm{uv})}{\partial \mathrm{y}}+\frac{\partial(\rho \mathrm{uw})}{\partial \mathrm{z}}$

c. Momentum Equations Momentum towards the y-axis:

$\frac{\partial(\rho \mathrm{u})}{\partial \mathrm{t}}+\frac{\partial(\rho \mathrm{uv})}{\partial \mathrm{x}}+\frac{\partial\left(\rho \mathrm{v}^{2}\right)}{\partial \mathrm{y}}+\frac{\partial(\rho \mathrm{uw})}{\partial \mathrm{z}}=-\frac{\partial \mathrm{p}}{\partial \mathrm{y}}+\frac{1}{\mathrm{R}_{\mathrm{r}}}\left(\frac{\partial \tau_{\mathrm{xy}}}{\partial \mathrm{x}}+\frac{\partial \tau_{\mathrm{yy}}}{\partial \mathrm{y}}+\frac{\partial \tau_{\mathrm{yz}}}{\partial \mathrm{z}}\right)$

\section{Research Methods}

This research was conducted to determine the characteristics of the velocity and pressure of $\mathrm{CO}$ gas in several distribution distances using the Computational Fluid Dynamic (CFD) method. The solutions of differential equations describing fluid flow are solved using SIMFLOW 3.1. The simulation process is divided into two stages, namely Pre-Processing and Processing. The PreProcessing stage includes making geometry and meshing models, identifying the mesh's boundaries, and checking the mesh. The processing stage includes determining boundary conditions, determining computational methods and parameters, and running simulations.

The input parameters used in the simulation process are given in Table 1. 
Table 1. Parameter Input

\begin{tabular}{cccc}
\hline No & \multicolumn{1}{c}{ Parameter } & Unit & Quantity \\
\hline 1 & Distance of $x$ & $\mathrm{~m}$ & $(10-70)$ \\
2 & Distance of $y$ & $\mathrm{~m}$ & 16 \\
3 & Distance of $z$ & $\mathrm{~m}$ & 24 \\
4 & Viscosity of CO & $\mathrm{m}^{2} / \mathrm{s}$ & $1.42 \times 10^{-5}$ \\
\hline
\end{tabular}

The geometry of the simulated gas source and distribution area is shown in Figure 2.1. The addition of blocks in the area around the head of the gas emission is intended to see in more detail the site to be analyzed. In this case, the length of the spread ( $x$-axis) is varied, while the blocks' size in the $y$ and $z$ directions is fixed. The design of the pollutant distribution area is given in Figure 1.

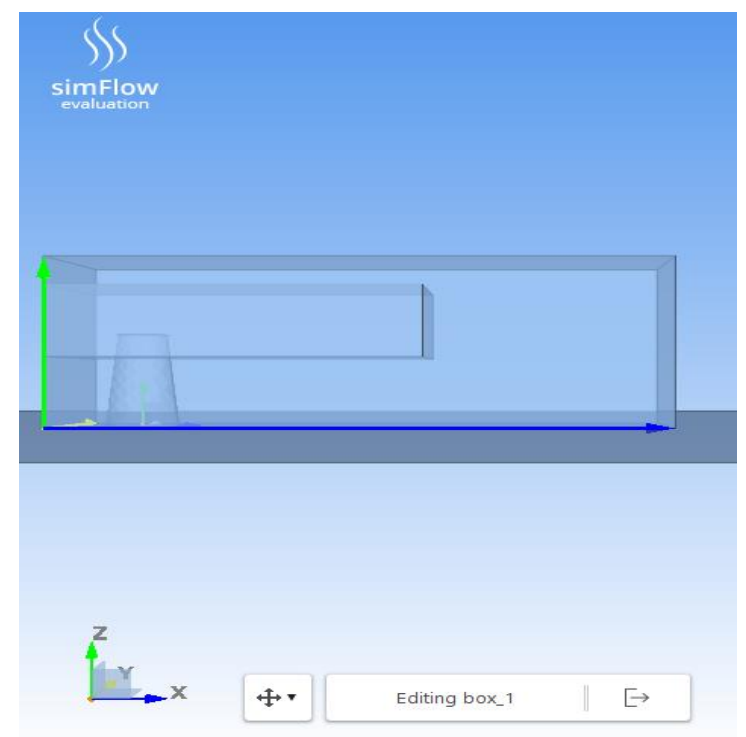

Figure 1 Design of pollutant distribution area

Arrangements for the meshing process are made on the mesh beam by setting the size to the minimum and maximum values as the cells size in the initial mesh. We measure the division value in the direction $(x, y, z)=(45,20,20)$. The next step is to determine the solver used in this simulation, namely pimple foam with a compressible flow and a transient time type. This selection is based on Mahan's research in 2009. The next step is to determine the boundary conditions to determine the conditions' character for each boundary. The Chimney_inlet boundary condition is set to be mass flow inlet with a constant flow rate of $10 \mathrm{~m}^{3} / \mathrm{s}$ and a pressure gradient of zero. The mass flow inlet is the area where the $\mathrm{CO}$ emission is released (the upper face of the stack). The second boundary condition, scalar type on Chimney_inlet, is changed to 1 . This means that it can operate in the range $0-1$. Value 1 indicates that the variable can operate $100 \%$. 
The inlet limit is set at the limit condition atmospheric inlet to define the flow current. The determination of the atmospheric inlet conditions also greatly affects the characteristics of the gas flow in the flue. These conditions establish a suitable inlet velocity profile for the atmospheric boundary layer. This profile is derived from the friction velocity, flow direction and vertical direction where, the flow direction is the direction that determines the value vector of the $x$-axis coordinate system. The vertical direction is a vector that defines the vertical axis parallel to the force of gravity.

The next step is setting the initial conditions by activating the initialize potential flow. Initialization is an initial estimate of the boundary conditions where we will start the calculation. This activation is performed to calculate the initial velocity and pressure by solving the potential flow problem before the actual simulation. This possible flow solution is much easier to obtain and can provide an excellent initial value of the velocity field. Before the time simulation process, the time step value is set to 0.001 with the last time limit of $200 \mathrm{~s}$. This simulation uses time interval one by selecting the adjustable run time type to save data for each simulation time break.

\section{Results and Discussion}

The results obtained from this study are the value of flow rate (velocity) and $\mathrm{CO}$ gas pressure from several variations in the distribution distance as a function of time. Observations were made at $10 \mathrm{~m}$ intervals, starting from a distribution distance of $10 \mathrm{~m}$ to $70 \mathrm{~m}$. The value of flow rate and pressure can be seen in Table 3.1. The flow velocity of $\mathrm{CO}$ gas was analyzed in three different flow directions, including the $x(U x), y(U y)$, and $z(U z)$ directions.

\section{Analysis of velocity on variations in the distribution distance}

By observing the velocity profile for each direction ( $U x, U y$, and $U z)$ as a function of the distance $\mathrm{x}$, it can be said that the velocity of $\mathrm{CO}$ gas in the $\mathrm{x}$-direction has the smallest value. This shows that the $\mathrm{CO}$ particles are slow to move in the horizontal $\mathrm{x}$-direction. The change in gas concentration is assumed to be small enough that $\mathrm{CO}$ gas can last long enough in the $\mathrm{x}$ direction. Besides, it is interesting to note that at a distance of $20 \mathrm{~m}, \mathrm{CO}$ gas always experiences a significant decrease in velocity throughout the observation time. In this case, the gas pressure factor is considered the main cause of the gas's characteristics. 


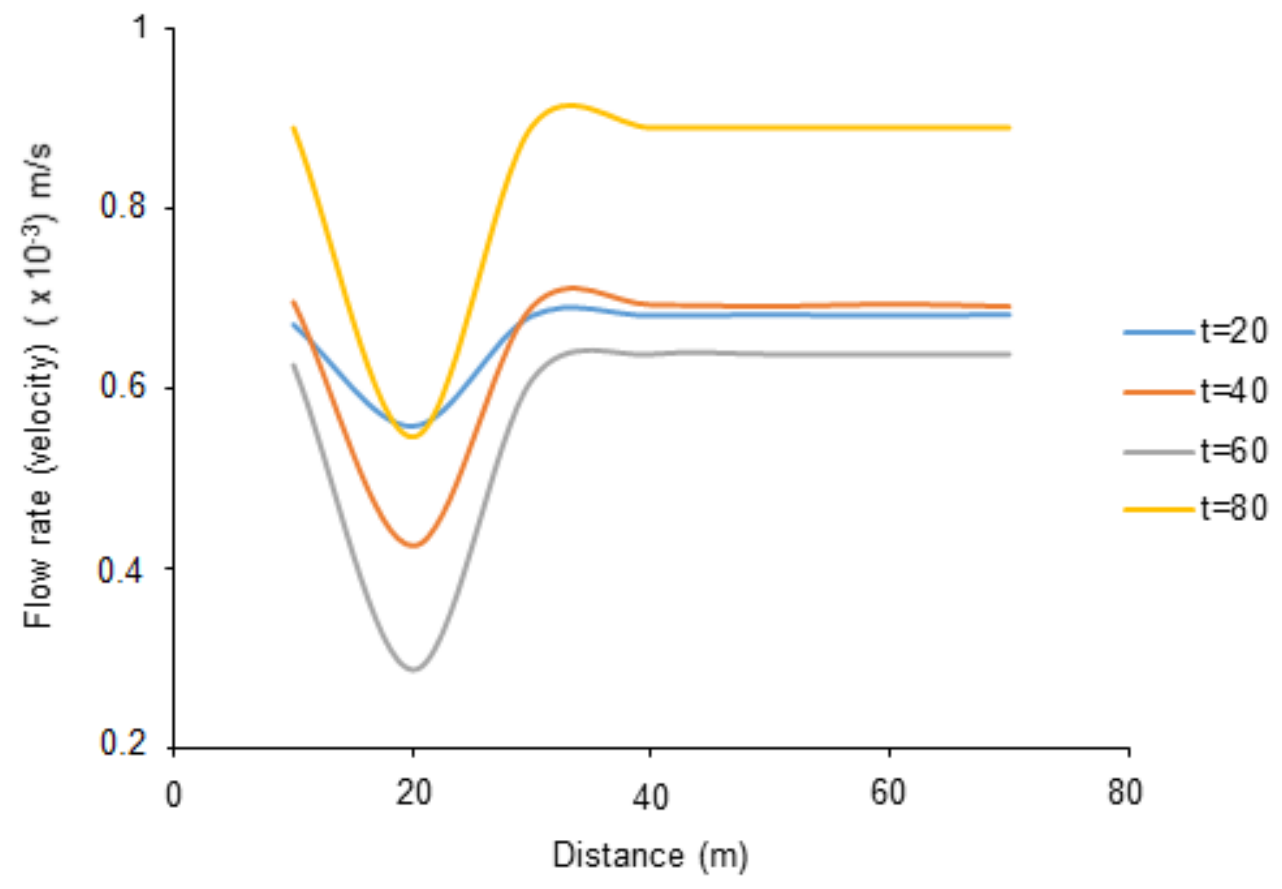

Figure 2. Flow rate of $\mathrm{CO}$ gas in the $\mathrm{x}$ direction $(\mathrm{Ux})$

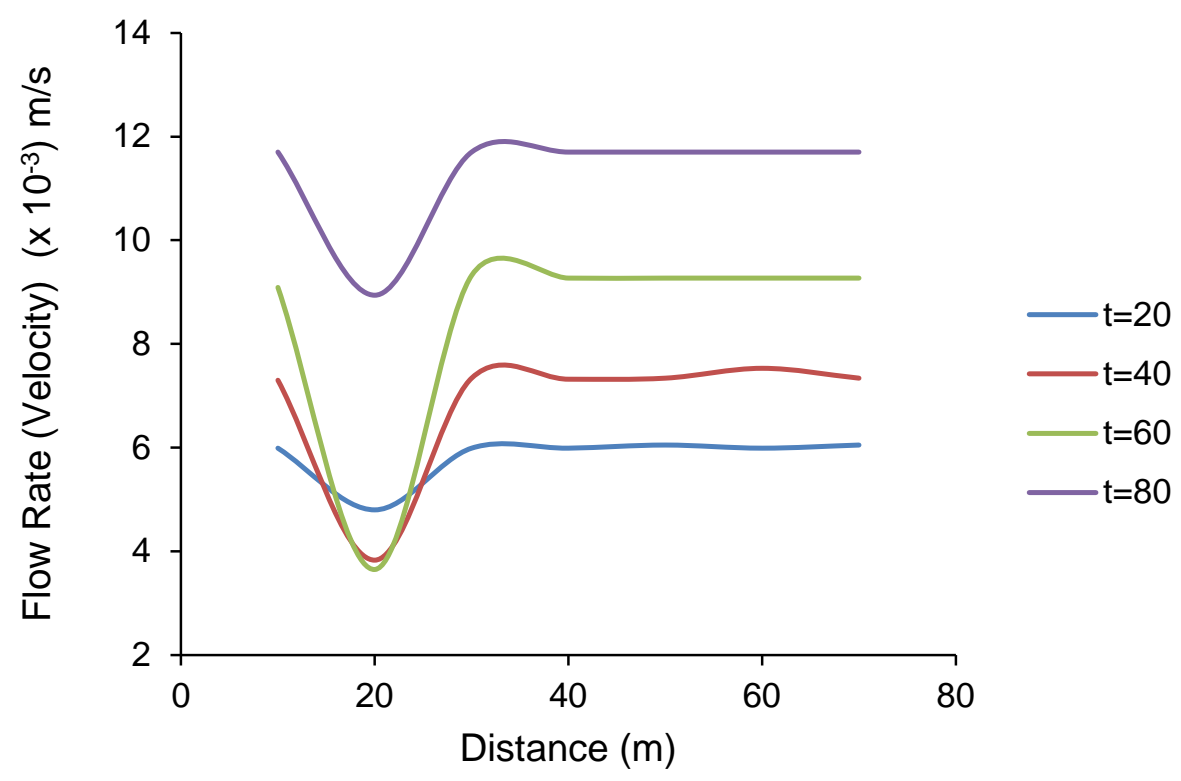

Figure 3. Flow rate of $\mathrm{CO}$ gas in the y direction (Uy) 


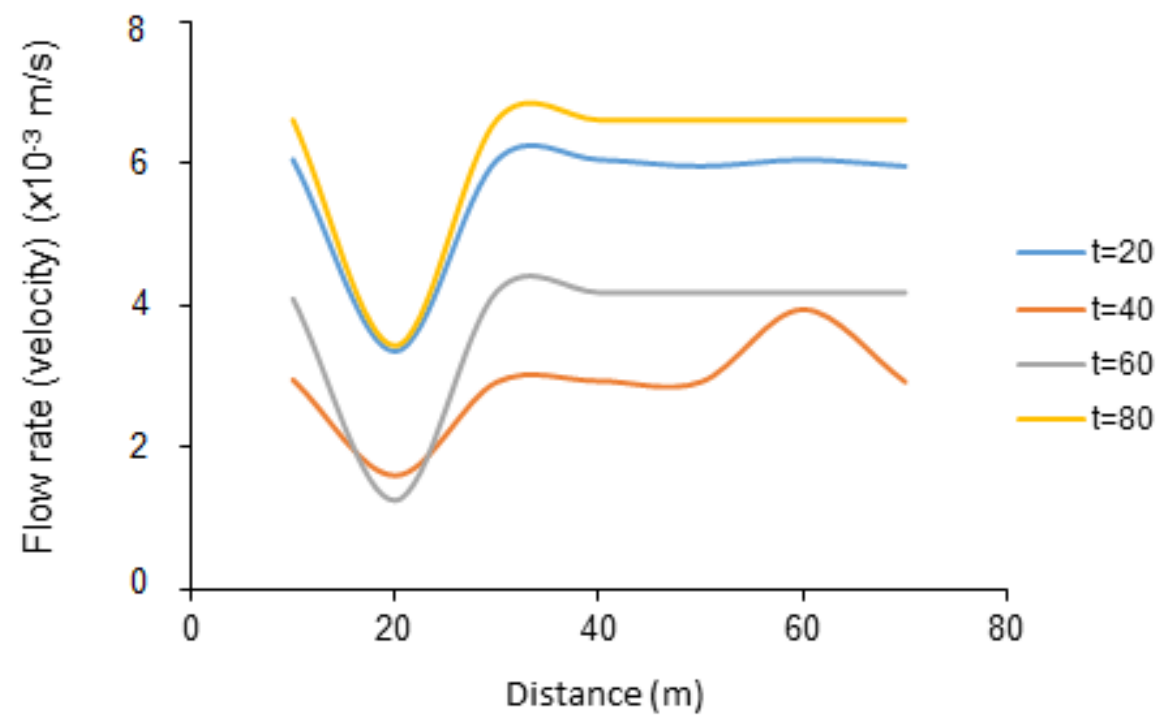

Figure 4. Flow rate of $\mathrm{CO}$ gas in the y direction (Uy)

In general, the velocity values on the $x, y$, and $z$ axes have the same pattern. To find out the resultant velocity, a detailed calculation of the resultant velocity of $\mathrm{CO}$ gas is shown in Table 2 . The $\mathrm{CO}$ gas flow rate profile at variations in gas movement mileage is presented in Figure 5 . It can be seen that the pattern of the flow rate represented at $20 \mathrm{~s}, 40 \mathrm{~s}, 60 \mathrm{~s}$, and $80 \mathrm{~s}$ has the same pattern even though the values are different.

Table 2. Resultant velocity at a distance of $10 \mathrm{~m}$ to $70 \mathrm{~m}$

\begin{tabular}{cccccccc}
\hline \multicolumn{7}{c}{ Resultant of Velocity $\times 10^{-3}(\mathrm{~m} / \mathrm{s})$} \\
\hline $\mathrm{t}(\mathrm{s})$ & $10 \mathrm{~m}$ & $20 \mathrm{~m}$ & $30 \mathrm{~m}$ & $40 \mathrm{~m}$ & $50 \mathrm{~m}$ & $60 \mathrm{~m}$ & $70 \mathrm{~m}$ \\
\hline 0.39 & 8.46 & 6.33 & 27.28 & 27.27 & 14.16 & 27.28 & 27.28 \\
10 & 14.25 & 8.69 & 14.15 & 14.25 & 27.28 & 14.25 & 14.16 \\
20 & 8.54 & 5.88 & 8.54 & 8.54 & 8.52 & 8.54 & 8.52 \\
30 & 8.53 & 5.23 & 8.53 & 8.53 & 8.52 & 8.53 & 8.52 \\
40 & 7.90 & 4.17 & 7.93 & 7.92 & 7.93 & 8.53 & 7.93 \\
50 & 8.67 & 4.04 & 8.65 & 8.65 & 8.65 & 8.66 & 8.65 \\
60 & 9.99 & 3.87 & 10.24 & 10.19 & 10.19 & 10.19 & 10.19 \\
70 & 12.51 & 7.91 & 12.51 & 12.51 & 12.53 & 12.51 & 12.53 \\
80 & 13.47 & 9.59 & 13.47 & 13.41 & 13.47 & 13.47 & 13.47 \\
90 & 14.76 & 10.03 & 14.76 & 14.76 & 14.79 & 14.76 & 15.54 \\
100 & 16.45 & 10.55 & 16.45 & 16.63 & 16.45 & 16.50 & 15.50 \\
110 & 16.95 & 11.26 & 17.52 & 17.38 & 22.46 & 17.38 & 17.52 \\
120 & 17.48 & 11.65 & 17.46 & 17.48 & 17.52 & 17.48 & 17.54 \\
130 & 17.71 & 10.63 & 17.69 & 17.73 & 17.73 & 17.71 & 17.69 \\
140 & 17.25 & 10.63 & 17.25 & 17.25 & 17.25 & 17.25 & 17.17 \\
150 & 15.68 & 10.59 & 15.68 & 15.60 & 15.68 & 15.68 & 15.68 \\
160 & 17.52 & 10.93 & 17.47 & 17.57 & 17.47 & 18.50 & 17.47
\end{tabular}




\begin{tabular}{cccccccc}
\hline \multicolumn{7}{c}{ Resultant of Velocity $\times 10^{-3}(\mathrm{~m} / \mathrm{s})$} \\
\hline $\mathrm{t}(\mathrm{s})$ & $10 \mathrm{~m}$ & $20 \mathrm{~m}$ & $30 \mathrm{~m}$ & $40 \mathrm{~m}$ & $50 \mathrm{~m}$ & $60 \mathrm{~m}$ & $70 \mathrm{~m}$ \\
\hline 170 & 18.71 & 8.99 & 18.64 & 18.71 & 18.71 & 18.70 & 18.71 \\
180 & 19.86 & 9.55 & 19.93 & 19.93 & 8.82 & 19.86 & 19.92 \\
190 & 20.13 & 8.78 & 20.13 & 20.21 & 20.13 & 20.21 & 20.14 \\
200 & 20.48 & 9.98 & 20.48 & 20.48 & 20.48 & 20.48 & 20.48 \\
\hline
\end{tabular}

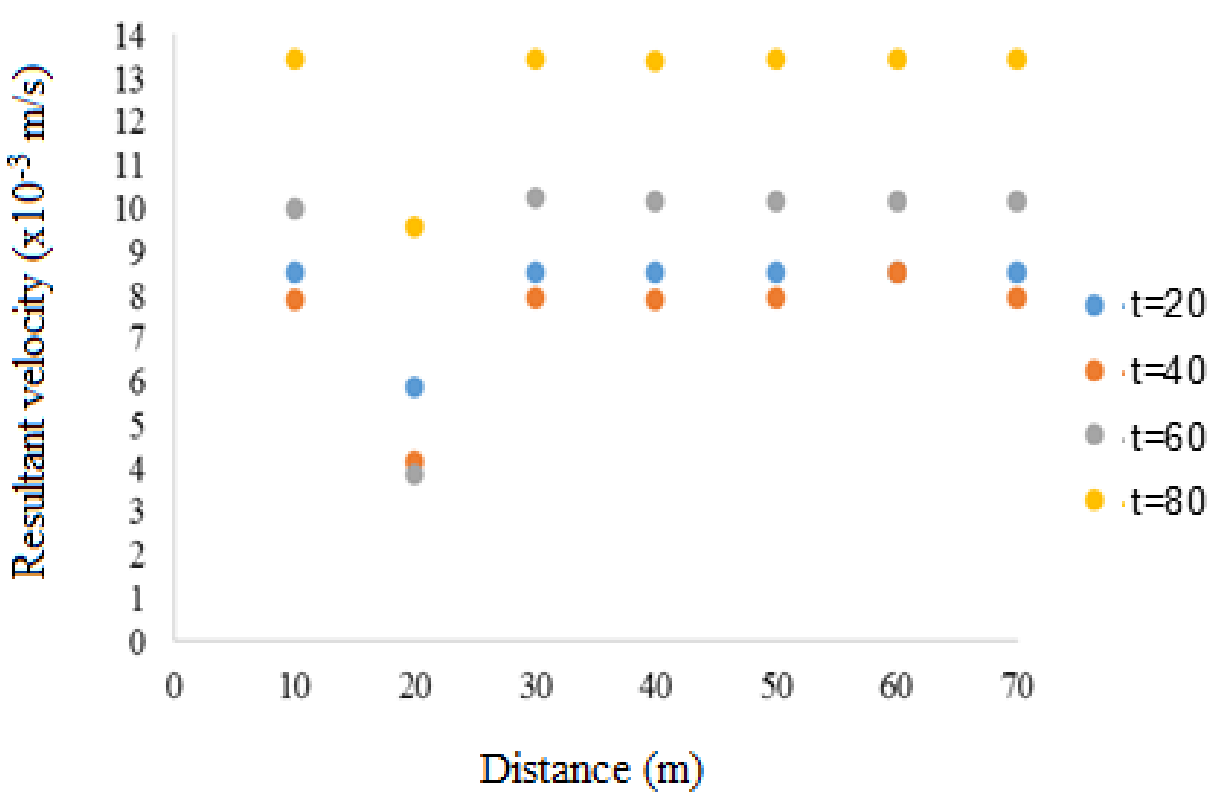

Figure 5. Profile of resultant velocity at distance variation

\section{Pressure analysis over distance variations}

The value of $\mathrm{CO}$ gas pressure is observed at several different positions in the $\mathrm{x}$-axis direction, namely at a distance of $10 \mathrm{~m}$ to $70 \mathrm{~m}$. The simulation results show that the pressure data fluctuates over 200 seconds, which is depicted on the pressure vs. distance graph, for a specific time (Figure 3.5). The highest amplitude is obtained at a distance of $20 \mathrm{~m}$. This corresponds to the amount of $\mathrm{CO}$ emitted. The longer the observation time and the farther the distance, the pressure decreases until it becomes a relatively stable state. The value of gas pressure indicates this at a relatively constant observation distance variation. $\mathrm{CO}$ gas pressure value data from several variations in the distribution distance is given in Table 3.

Table 3. pressure values at a distribution distance of $20 \mathrm{~m}$ to $70 \mathrm{~m}$

\begin{tabular}{cccccccc}
\hline \multirow{2}{*}{$\mathrm{t}(\mathrm{s})$} & \multicolumn{7}{c}{ Gas Pressure of CO $\left(10^{-2} \mathrm{~Pa}\right)$} \\
\cline { 2 - 8 } & $10 \mathrm{~m}$ & $20 \mathrm{~m}$ & $30 \mathrm{~m}$ & $40 \mathrm{~m}$ & $50 \mathrm{~m}$ & $60 \mathrm{~m}$ & $70 \mathrm{~m}$ \\
\hline 0.39 & 5.90 & 2.01 & 4.80 & 4.80 & 4.80 & 4.80 & 4.80 \\
10 & 2.00 & 1.00 & 2.01 & 2.00 & 2.00 & 2.00 & 2.01 \\
20 & 1.71 & 1.59 & 1.71 & 1.70 & 1.71 & 1.71 & 1.71 \\
30 & 1.86 & 1.84 & 1.86 & 1.85 & 1.86 & 1.85 & 1.86
\end{tabular}




\begin{tabular}{cccccccc}
\hline \multirow{2}{*}{$\mathrm{t}(\mathrm{s})$} & \multicolumn{7}{c}{ Gas Pressure of $\mathrm{CO}\left(10^{-2} \mathrm{~Pa}\right)$} \\
\cline { 2 - 8 } & $10 \mathrm{~m}$ & $20 \mathrm{~m}$ & $30 \mathrm{~m}$ & $40 \mathrm{~m}$ & $50 \mathrm{~m}$ & $60 \mathrm{~m}$ & $70 \mathrm{~m}$ \\
\hline 40 & 2.10 & 1.62 & 2.10 & 2.10 & 2.10 & 2.10 & 2.10 \\
50 & 2.27 & 2.25 & 2.27 & 2.26 & 2.27 & 2.26 & 2.27 \\
60 & 2.72 & 2.44 & 2.71 & 2.72 & 2.72 & 2.72 & 2.72 \\
70 & 2.82 & 2.36 & 2.82 & 2.82 & 2.83 & 2.82 & 2.83 \\
80 & 2.91 & 2.82 & 2.91 & 2.87 & 2.87 & 2.87 & 2.87 \\
90 & 3.36 & 3.36 & 3.36 & 3.36 & 3.38 & 3.36 & 3.38 \\
100 & 3.24 & 3.19 & 3.38 & 3.25 & 3.23 & 3.26 & 3.66 \\
110 & 3.35 & 3.39 & 3.39 & 3.37 & 3.37 & 3.37 & 3.39 \\
120 & 3.37 & 2.36 & 3.38 & 3.37 & 3.37 & 3.37 & 3.37 \\
130 & 2.98 & 2.97 & 3.40 & 3.00 & 3.00 & 2.97 & 2.93 \\
140 & 2.98 & 3.00 & 3.00 & 2.99 & 2.98 & 3.00 & 3.00 \\
150 & 3.12 & 3.08 & 2.95 & 3.08 & 3.10 & 3.11 & 3.10 \\
160 & 3.31 & 3.28 & 3.24 & 3.27 & 3.24 & 3.49 & 3.24 \\
170 & 3.60 & 3.57 & 3.58 & 3.59 & 3.60 & 3.57 & 3.60 \\
180 & 3.73 & 3.71 & 3.73 & 3.71 & 3.71 & 3.70 & 3.71 \\
190 & 3.33 & 3.32 & 3.33 & 3.32 & 3.33 & 3.37 & 3.32 \\
200 & 3.44 & 3.34 & 3.44 & 3.43 & 3.44 & 3.44 & 3.44 \\
\hline
\end{tabular}

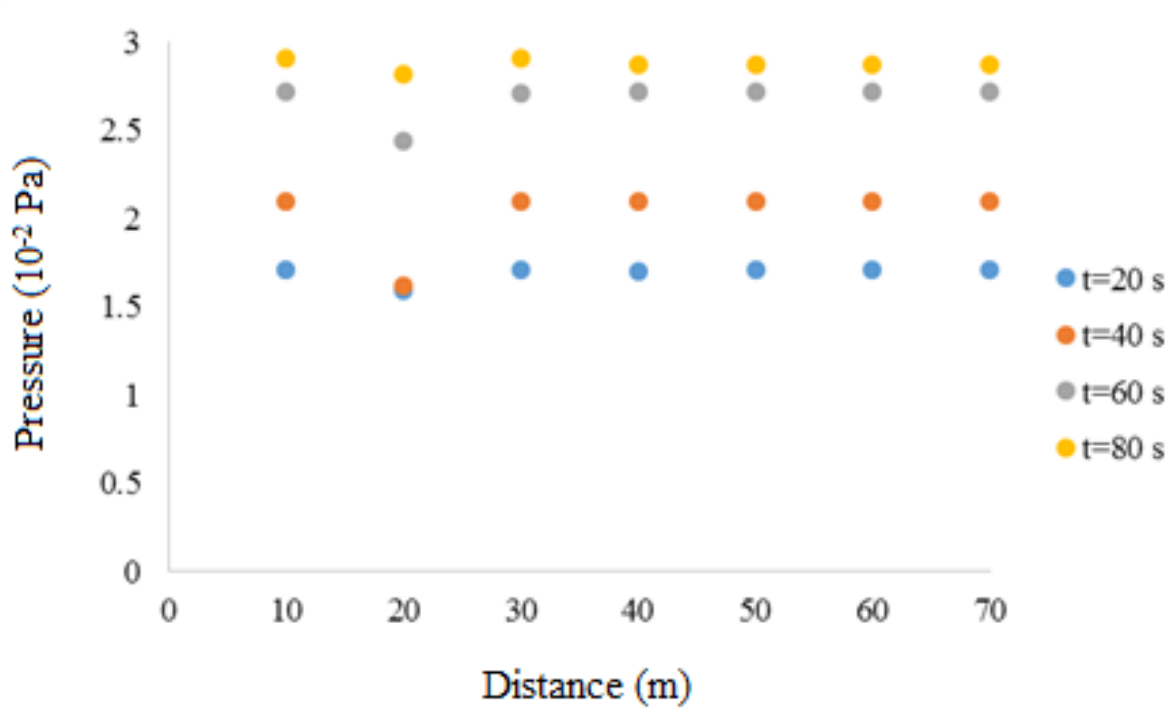

Figure 6. Pressure variation profile as a function of distance

Based on Figure 6., we can see that the pressure distribution of $\mathrm{CO}$ gas has almost the same characteristics as the gas velocity distribution. Therefore, changes in the velocity values that occur in the $\mathrm{CO}$ gas flow can be affected by the gas pressure state. The simulation results show that the higher the gas pressure, the greater the gas flow velocity produced. The resulting gas pressure at a distance of 30 to $70 \mathrm{~m}$ does not show much change. One of the causes of this situation is that the simulated $\mathrm{CO}$ gas characteristics are limited to incompressible gas conditions. The pressure state at 40 seconds, for the position of the gas as far as $20 \mathrm{~m}$, does not show a significant change. The data obtained in this case is $0.5 \times 10-2 \mathrm{~Pa}$. In Figure 6 we can see that the pressure-distance relationship curve has the same shape as the velocity- 
distance curve. Thus, the two parameters can be said to be correlated. Ni'am states that the gas pressure is directly proportional to the velocity of the gas produced [11]. The graph of the pressure to velocity relationship is shown in Figure 7.

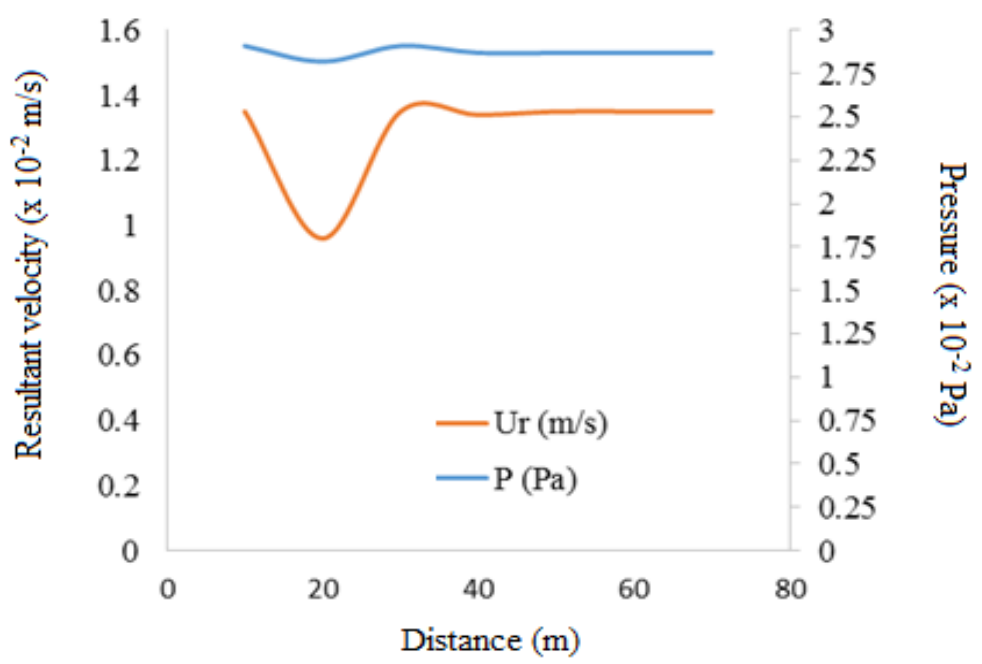

Figure 7. Relationship between pressure and resultant velocity at $80 \mathrm{~s}$ observation time.

\section{Conclusions}

The $\mathrm{CO}$ gas flow rate as a function of the distribution distance has the same distribution pattern for the entire observation time. The flowing movement is relatively stable after a distance of 30 $\mathrm{m}$. The minimum pressure of $\mathrm{CO}$ gas is generated at a distance of $20 \mathrm{~m}$, while at a distance of $30 \mathrm{~m}$ to $70 \mathrm{~m}$, it does not show a large enough change. The amount of $\mathrm{CO}$ gas pressure is directly proportional to the magnitude of the velocity of the gas produced.

\section{ACKNOWLEDGEMENTS}

The Author thanks to LP2M Universitas Jember for providing research funding assistance through Hibah Keris 2018.

\section{References}

[1] S. Serkey, F. Jassen, S. Wallah, 2011, Tingkat Pencemaran Udara CO Akibat Lalu Lintas Dengan Model Prediksi Polusi Udara Skala Mikro, Jurnal IImiah Media Engineering, volume 1(2), page 119-120.

[2] Akmal, 2009, Dampak Gas CO terhadap Kesehatan, http://vhatal(Akmal): dampak gas CO terhadap kesehatan.htm, accessed on Januari 25, 2019.

[3] S. Benny, 2005, Telaah Studi AMDAL Pada Tahap Operasional Pabrik Peleburan Timah (Smelter) PT. Laba-Laba Multindo Pangkal Pinang-Bangka Belitung, Skripsi, Semarang, Fakultas Teknik UNISSULA. 
[4] M. Weaver, Lindell K, 2009, Carbon Monoxide Poisoning, The New England Journal of Medicine, 360, page 1217-25.

[5] T. W. Hubber, A. Bell, B. Schwarz W, 2006, Application Of CFD Simulations for ShortRange Atmospheric Dispersion Over Open Fields And Within Arrays of Buildings, Proceeding of the symposium at the 14th on the applications of air pollution meteorology, Atlanta, 30 Januari -2 Februari.

[6] F. Fathoni, 2016, Studi Numerik Sudden Expansion Meso Combustor Pada Micro Power Generator, Skripsi, Jember, Teknik Mesin Fakultas Teknik Universitas Jember.

[7] M. Victor, 2009, Simulasi Penyebaran SO2 dari Emisi Cerobong Menggunakan Computational Fluid Dynamic (CFD), Skripsi, Bogor, Institut Pertanian Bogor.

[8] F. Fadhili, 2016, Studi Numerik Studi Numerik Sudden Expansion Meso Combustor Pada Micro Power Generator, Skripsi, Jember, Teknik Mesin Fakultas Teknik Universitas Jember.

[9] A. A. Gazali, 2018, Analisa Aliran Fluida Menggunakan CFD Dengan Variabel Viscosity Pada Preproses Injeksi Molding, Skripsi, Jember, Teknik Mesin Fakultas Teknik Universitas Jember.

[10] H. K. Versteeg, W. Malalasekera, 1995, An Introduction to Computational Fluid Dynamics The Finite Volume Method, New York, John Wiley \& Sons.

[11] A. G. Ni'am, 2009, Simulasi Dispersi Gas Polutan S02, H2S, dan CO Dengan Menggunakan Program Computational Fluid Dynamic (CFD), Skripsi, Bogor, Institut Pertanian Bogor. 